\title{
APRIMORAMENTO DE ATRIBUTOS COMERCIALMENTE DESEJÁVEIS EM ASTER SP CULTIVAR WHITE MASTER ATRAVÉS DO USO DE REGULADORES DO CRESCIMENTO VEGETAL
}

\author{
EXCELLENCE OF DESIRABLE COMMERCIAL ATTRIBUTES IN ASPER SP OF \\ WHITE MASTER CULTIVAR USING VEGETABLE GROWTH REGUTATORS
}

\author{
Marlene de Lurdes FERRONATO \\ Orientador: Professor Dr. Adaucto Bellarmino PEREIRA NETTO (Departamento de Botânica - UFPR)
}

\begin{abstract}
RESUMO
O mercado mundial de plantas ornamentais se caracteriza por investimento constante de recursos na busca do aprimoramento de características comerciais desejáveis. $O$ interesse crescente do mercado mundial de plantas ornamentais pelo Aster sp (Asteraceae) se justifica pela uniformidade de suas flores e produção constante ao longo do ano. Em áster, o número de capítulos, o comprimento das hastes e o tempo de vida útil dos capítulos são caraterísticas de grande interesse comercial que podem, potencialmente, ser aprimoradas através de alterações nos níveis endógenos de reguladores do crescimento vegetal. Este trabalho teve como objetivos aprimorar características morfológicas de interesse comercial em Aster $s p$, cultivar White Master, e também prolongar o tempo de vida útil da planta após o corte, através da aplicação de reguladores do crescimento vegetal. Os experimentos foram instalados na casa de vegetação do Departamento de Fitotecnia e Fitossanitarismo da Universidade Federal do Paraná, e conduzidos sob delineamento experimental inteiramente casualizado. Tratamentos com aminoetoxivenilglicina (AVG) combinado com tiossulfato de prata (STS) consistiram de aplicações de soluções nas concentrações de: 0, 150, 300, 600 uM, para o AVG e $1 \mathrm{mM}$ para o STS, sob a forma de "spray". Tratamentos com STS consistiram de aplicações de soluções em concentrações 0, 200 (30 min), 200 (60 min) 1000 uM (30 min). Tratamentos com Prolamina (benziladenina + GA4 + GA7) combinada com STS

consistiram na pulverização de soluções em concentrações $0,250,500$ e 1000 mg.L-1 de Prolamina seguida de imersão em 200uM de STS por 60 min. Tratamentos com 1metilciclopropano (1-MCP) consistiram na manutenção de capítulos em atmosfera enriquecida com 0, 100 e 200uL.L-1 de 1-MCP. Os parâmetros avaliados foram: comprimento das hastes principais, número de capítulos fechados, abertos e murchos, massa verde das hastes e número de flores liguladas do raio e flores tubulosas do disco em senescência. O tratamento com 300uM de AVG combinado com STS ocasionou um retardo estatisticamente significante $(p=5 \%)$ no murchamento dos capítulos. No tratamento com 1000uM de STS por $30 \mathrm{~min}$ foi observada manutenção de maior número de capítulos abertos por haste. A aplicação de 250 e 500 mg.L-1 de Prolamina mostrou-se associada ao tratamento com STS possibilitou a manutenção do maior número capítulos abertos ao longo do experimento. As doses 100 e 200 uL.L-1 de 1-MCP, não se mostraram capazes de retardar significativamente $(p=5 \%)$ o processo de senescência nos capítulos (flores liguladas do raio e flores tubulosas do disco) de plantas de áster. Conclui-se, que o prolongamento da vida útil de áster pode ser alcançado pelos tratamentos com produtos químicos conhecidos por inibir a biossíntese (AVG) ou o mecanismo de ação (STS) do etileno, ou por inibir a senescência de órgãos vegetais (Prolamina).
\end{abstract}

ABSTRACT

The ornamental plants's industry is constantly searching for improved cultivars. Market for aster (Aster $\underline{s p} \mathrm{cV}$ White Master) has grown, steadily during the last years increasing the importance of this plant in the industry. This growing interest is due to the uniformity of the aster's flowers and also to the possibility of growing this species throughout the year. Number of flowers, branch length and fresh weight, and shelf life of cut flowers are major attributes contributing to their aesthetic quality, marketability and price. In an attempt to improve these attributes, we treated plants or cut flowers of aster with chemicals known to stimulate branching and to delay senescence. The experiments were carried out in a green-house (Departamento de Fitotecnia e Fitossatjitarisxno da Universidade Federal do Paraná) in a completely randomized design. Aminoethoxyvynilglycine (AVG) at 0 , 150, 300 and $600 \mu \mathrm{M}$, followed by immersion $1 \mathrm{mM}$ silver thiosulfate (STS), was sprayed on whole plants. Whole plants were also sprayed with Prolamin ${ }^{T M}$ (benzyladenine+GA 4 ) at $0,250,500$ and $1000 \mathrm{mg} \cdot \mathrm{L}^{-1}$, followed by immersion in $200 \mu \mathrm{M}$ STS for 60 minutes. Aster branches were immersed in 0, 200 (30 or 60 minutes) and $1.000 \mu \mathrm{M}$ (30 minutes) STS, as well. Excised flowers were treated with 0,100 or $200 \mu L . L^{-1}$ of 1-methylcyclopropane (1-MCP). Changes on the number of flowers, as well as their appearance (open, closed or wilted), branch length and fresh weight, and the time course of flowers presenting necrotic areas were recorded. Plants treated with $300 \mu \mathrm{M}$ AVG presented a significant delay $(p=5 \%)$ on flower wilting, compared to the untreated plants (0 $\mu$ M AVG). Branches imnmersed in $1.000 \mu \mathrm{M}$ STS for 30 minutes or sprayed with 250 or $500 \mathrm{mg}^{-1} \mathrm{~L}^{-1}$ Prolamin $^{T M}$ also presented delay on flower wilting, being the effect remarkable for Prolamin ${ }^{T M}(p=5 \%)$. The doses of 100 and $200 \mu \mathrm{L} . L^{-1}$ of $1-$ $M C P$, were shown not to be able to delay significantly ( $p=5 \%)$ the senescence process in the capitulum (ligulated flowers of the ray and tubulous flowers of the disk) of aster plants. Excised flowers treated with 1-MCP presented delay on the arise of necrotic areas, when compared to the controls $\left(0 \mu \mathrm{L} . L^{-1} 1-M C P\right)$. In conclusion, prolongation of shelf life in aster can be achieved by treatments with chemicals known inhibit the ethylene biosynthesis (AVG) or signal transduction pathway (STS), or to inhibit organ senescence (Prolamin ${ }^{T M}$ ). 